\title{
Interferences of urinary tract infection in the measurement of urinary nitrous oxide
}

\author{
P Apostoli, M Gelmi, L Alessio, A Turano
}

\begin{abstract}
Objectives-To investigate the effective role of micro-organisms in producing $\mathrm{N}_{2} O$. Methods-The $\mathrm{N}_{2} \mathrm{O}$ in either urine samples inoculated with 24 microbial strains or urine samples from patients with urinary tract infections were measured.

Results-Gram negative bacilli generally produced high amounts of nitrous oxide $\left(\mathbf{N}_{2} \mathbf{O}\right)$, whereas Gram positive cocci and yeasts did not. The production of $\mathrm{N}_{2} \mathrm{O}$ depends on the incubation time and follows exponential kinetics, reaching a plateau at 48 hours. Furthermore, the results of urinocultures agreed well with $\mathbf{N}_{2} \mathrm{O}$ concentrations found in urine samples: samples negative for bacteria were found to contain very low concentrations of $\mathrm{N}_{2} \mathrm{O}$ whereas those positive-for example, for Enterobacteriaceae-gave highest $\mathbf{N}_{2} \mathbf{O}$ values.

Conclusion-The urinary tract infections caused by Gram negative bacilli are important confounding factors in biological monitoring practices of exposure to inhalation anaesthetics. The current methods adopted to avoid these factors (urine acidification, storage of samples at $4^{\circ} \mathrm{C}$ ) are not good enough because of the relative acid tolerance of some strains and the production of $\mathrm{N}_{2} \mathrm{O}$ directly into the bladder.
\end{abstract}

(Occup Environ Med 1996;53:591-594)

Keywords: nitrous oxide; urinary tract infection; biological monitoring; confounding factors

The biological monitoring of exposure to anaesthetic gas is more and more frequently carried out by measuring the concentration of nitrous oxide $\left(\mathrm{N}_{2} \mathrm{O}\right)$ in urine. It has been reported, however, that urinary tract infections can significantly interfere with the concentration of $\mathrm{N}_{2} \mathrm{O}$ in urine samples due to the capability of a variety of microbial species to produce this gas by different mechanisms.

The measurement of urinary nitrous oxide $\left(\mathrm{N}_{2} \mathrm{O}\right)$ as a reliable biological indicator of exposure to this anaesthetic and, possibly, also to mixtures containing halogenated compounds, has increased in recent years. In fact, considering the low solubility of the anaesthetic in the blood and assuming a constant production of urine during exposure and no exchanges at the bladder wall level, the urinary concentration of $\mathrm{N}_{2} \mathrm{O}$ can be considered to be directly proportional to the air concentration evaluated by a time weighted environmental sample. ${ }^{1-5}$

During our routine monitoring of surgery room staff, we found very high values of urinary $\mathrm{N}_{2} \mathrm{O}$ in about $2 \%$ of the subjects, that could not be attributed solely to the gas exposure: in their urine samples $\mathrm{N}_{2} \mathrm{O}$ concentrations ranged from 150 to $750 \mathrm{mg} / \mathrm{l}$, but in samples from other workers operating in the same rooms the values ranged from 5 to 70 $\mathrm{mg} / \mathrm{l}$. This evidence, recently confirmed by other authors, ${ }^{6}$ happened despite the close aderence to the rules to prevent all possible causes of preanalytical errors, ${ }^{7}$ - that is, collection of samples in non-contaminated areas, acidification of urine to avoid endogenous $\mathrm{N}_{2} \mathrm{O}$ production, storage at $4^{\circ} \mathrm{C}$, and measurement within 24 hours of sample collection.

It has been reported ${ }^{8}$ that urinary tract infection can significantly interfere with the concentration of $\mathrm{N}_{2} \mathrm{O}$ in urine samples. In fact, a variety of microbial species, including those most frequently responsible for urinary infection such as Enterobacteriaceae, are capable of producing $\mathrm{N}_{2} \mathrm{O}$ by different mechanisms. ${ }^{9}$

To gain further insight into the effective role of microorganisms as sources of $\mathrm{N}_{2} \mathrm{O}$, we investigated $\mathrm{N}_{2} \mathrm{O}$ formation in urine samples inoculated with different microbial strains and the correlation between the amount of $\mathrm{N}_{2} \mathrm{O}$ detected and the result of urine cultures from patients with urinary tract infections.

Materials and methods

PRODUCTION OF $\mathrm{N}_{2} \mathrm{O}$ BY DIFFERENT MICROBIAL SPECIES

Micro-organisms

The following organisms, all isolated from clinical materials (sputum, urine, and blood), were cultured on agar plates and identified at the Laboratory of Microbiology of the Spedali Civili of Brescia, on the basis of their morphology and metabolic activities: Staphylococcus aureus, strain No 1; Staphylococcus aureus, strain No 2; Staphylococcus aureus, strain No 3; Streptococcus agalactiae (group B), strain No 1; Streptococcus agalactiae (group B), strain No 2; Enterococcus faecalis (group D), strain No 1; Enterococcus faecalis (group D), strain No 2; Streptococcus sanguis; Escherichia coli, strain No 1; Escherichia coli, strain No 2; Escherichia coli, 
Figure 1 Typical gas chromatograms: peaks (arrows) in $A, B$, and $C$, correspond to $\mathrm{N}_{2} \mathrm{O}$ concentration of $0.3,1.0$ and $78.5 \mu \mathrm{g} / \mathrm{l}$ respectively. strain No 3; Klebsiella pneumoniae; Klebsiella ozaenae; Enterobacter cloacae; Enterobacter aerogenes; Proteus mirabilis; Proteus vulgaris; Serratia marcescens; Pseudomonas aeruginosa, strain No 1; Pseudomonas aeruginosa, strain No 2; Pseudomonas aeruginosa, strain No 3; Candida albicans; Candida tropicalis, and Torulopsis glabrata.

Urine-A urine sample from a healthy donor, negative for the presence of bacteria, leucocytes, and for the nitrate test, was used as substrate for the microbial growth.

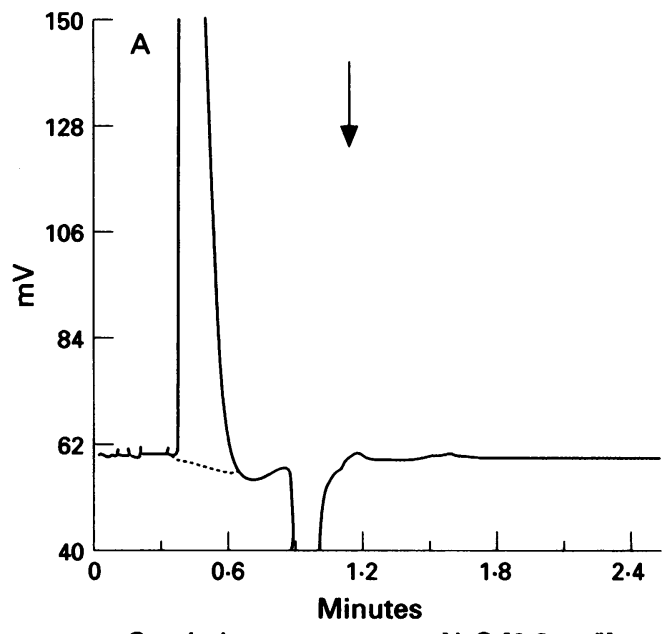

Staphylococcus aureus: $\mathrm{N}_{2} \mathrm{O}[0.3 \mu \mathrm{g} / \mathrm{l}]$
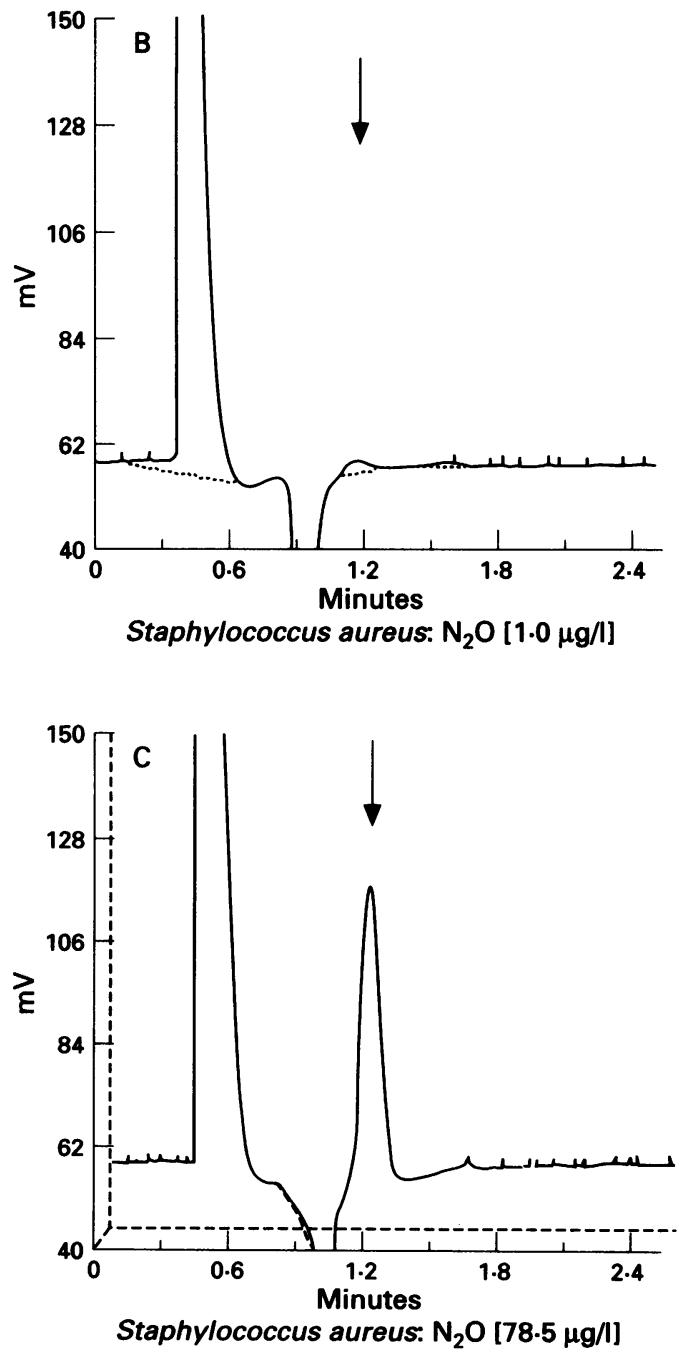

Procedure-10 ml gas proof glass vials with teflon caps were filled with $3 \mathrm{ml}$ of urine; each vial was inoculated with $100 \mu$ l of suspension of a single strain in sterile saline solution to give a final bacterial count corresponding to $1-5 \times 10^{6} \mathrm{cfu} / \mathrm{ml}$. Vials were tightly closed and incubated at $37^{\circ} \mathrm{C}$ for 24 hours.

\section{$\mathrm{N}_{2} \mathrm{O}$ PRODUCTION KINETICS}

To study the kinetics of production of $\mathrm{N}_{2} \mathrm{O}$, six vials were filled with $3 \mathrm{ml}$ of a sample of urine, negative for bacteria, and were inoculated with Enterobacter aerogenes (bacterial count $\left.1 \times 10^{5} \mathrm{cfu} / \mathrm{ml}\right)$. The suspensions were incubated at $37^{\circ} \mathrm{C}$ and the amount of $\mathrm{N}_{2} \mathrm{O}$ produced was measured at $0,2,5,8,24$, and 48 hours after inoculation.

$\mathrm{N}_{2} \mathrm{O}$ MEASUREMENT IN URINE CULTURES

Urine samples were collected from 16 patients admitted in various units of Spedali Civili of Brescia and $10 \mathrm{ml}$ of each sample was inoculated by a sterile calibrated loop on the following solid media (all from Biomerieux): CLED agar, suitable for the isolation of all common bacteria and yeasts; blood agar containing the antimicrobial drug aztreonam $(150 \mathrm{mg} / \mathrm{l})$ for the selection of Gram positive species; McConkey agar for the selection of Enterobacteriaceae and Pseudomonadaceae. The urine samples, stored overnight at $4^{\circ} \mathrm{C}$, were then transferred in vials and analysed for $\mathrm{N}_{2} \mathrm{O}$ content. For four patients the $\mathrm{N}_{2} \mathrm{O}$ measurement was carried out immediately after harvesting the sample.

\section{$\mathrm{N}_{2} \mathrm{O}$ MEASUREMENT}

The urinary $\mathrm{N}_{2} \mathrm{O}$ content was measured by head space gas chromatography. ${ }^{3}$ The vials were set in a thermostatic, automatic sampler (model FISONS HS800) and $250 \mathrm{ml}$ aliquots of head space air were automatically transferred to the gas chromatograph (model FISONS HS8560 HRGC Mega 2). The analytical conditions were as follows:

steel column, $2 \mathrm{~m}$ in length, $0.3 \mathrm{~cm}$ in diameter, filled with Poropack Q 80/100 mesh resin; injection temperature, $200^{\circ} \mathrm{C}$; bake temperature, $40^{\circ} \mathrm{C}$; carrier gas, for ECD nitrogen, carrier at $20 \mathrm{ml} / \mathrm{min}$, make up $30 \mathrm{ml} / \mathrm{min}$; working conditions, ECD temperature detector $260-285^{\circ} \mathrm{C}$.

The calibration curve was constructed by use of $\mathrm{N}_{2} \mathrm{O}$ cylinders with certified concentrations from 100 to $500 \mathrm{ppm}$.

Figure 1 shows, as examples, three chromatograms with $\mathrm{N}_{2} \mathrm{O}$ concentrations of 0.3 , 1.0 , and $78.5 \mathrm{mg} / 1$.

The calibration curves were constructed by adding known amounts of $\mathrm{N}_{2} \mathrm{O}$ with a microsyringe to closed vials containing $3 \mathrm{ml}$ of urine to make 1,10 , and $100 \mathrm{mg} / \mathrm{l}$. The aliquots of $\mathrm{N}_{2} \mathrm{O}$ were extracted from vials in which the diluted $\mathrm{N}_{2} \mathrm{O}$ came from cylinders with a known concentration of $100 \mathrm{ppm}$. Concentrations of urinary $\mathrm{N}_{2} \mathrm{O}$ were calculaed by the method of Imbriani et al. ${ }^{3}$ The detection limit was assessed at $0.2 \mathrm{mg} / 1$ and the coefficient of variation varied from $0.5 \%$ to $1 \%$. 
Table 1 Urinary $\mathrm{N}_{2} \mathrm{O}$ with various infections

\begin{tabular}{lc}
\hline Bacterial strain & $N_{2} \mathrm{O}$ in urine $(\mu g / l)^{*}$ \\
\hline Staphylococcus aureus, strain 1 & $0 \cdot 1$ \\
Staphylococcus aureus, strain 2 & $3 \cdot 4$ \\
Staphylococcus aureus, strain 3 & $0 \cdot 9$ \\
Streptococcus agalactiae (group B), strain 1 & $0 \cdot 8$ \\
Streptococcus agalactiae (group B), strain 2 & $4 \cdot 2$ \\
Enteroccus faecalis (group D), strain 1 & $0 \cdot 6$ \\
Enteroccus faecalis (group D), strain 2 & $2 \cdot 3$ \\
Streptococcus sanguis & $0 \cdot 1$ \\
Escherichia coli, strain 1 & $132 \cdot 8$ \\
Escherichia coli, strain 2 & $169 \cdot 2$ \\
Escherichia coli, strain 3 & $464 \cdot 7$ \\
Klebsiella pneumoniae & $181 \cdot 9$ \\
Klebsiella ozaenae & $210 \cdot 2$ \\
Enterobacter cloacae & $134 \cdot 0$ \\
Enterobacter aerogenes & $381 \cdot 2$ \\
Proteus mirabilis & $78 \cdot 5$ \\
Proteus vulgaris & $87 \cdot 2$ \\
Serratia marcescens & $373 \cdot 4$ \\
Pseudomonas aeruginosa, strain 1 & $284 \cdot 5$ \\
Pseudomonas aeruginosa, strain 2 & $245 \cdot 7$ \\
Pseudomonas aeruginosa, strain 3 & $218 \cdot 3$ \\
Candida albicans & $1 \cdot 0$ \\
Candida tropicalis & $0 \cdot 1$ \\
Torulopsis glabrata & $1 \cdot 5$ \\
\hline
\end{tabular}

*Urinary $\mathrm{N}_{2} \mathrm{O}$ concentration measured by headspace gas chromatography after incubation of samples at $37^{\circ} \mathrm{C}$ for $24 \mathrm{~h}$.

Figure 2 Kinetics of $\mathrm{N}_{2} \mathrm{O}$ production by Enterobacter aerogenes.

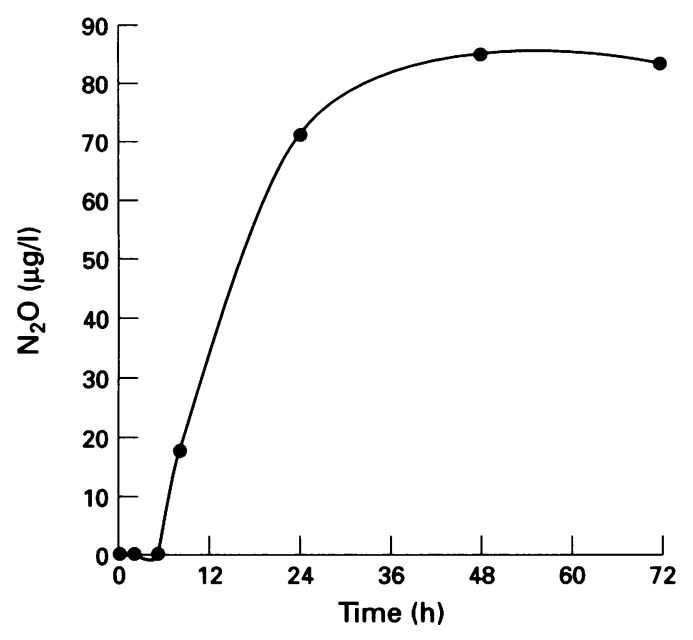

Results

$\mathrm{N}_{2} \mathrm{O}$ FORMATION IN URINE SAMPLES INOCULATED WITH DIFFERENT MICROBIAI SPECIES

Table 1 shows results of samples incubated for 24 hours at $37^{\circ} \mathrm{C}$.

It can be seen that micro-organisms behave differently in their production of $\mathrm{N}_{2} \mathrm{O}$. Gram negative bacilli generally produce high amounts of $\mathrm{N}_{2} \mathrm{O}$, whereas Gram positive cocci and yeasts produce only small amounts of

Table 2 Correlation between $\mathrm{N}_{2} \mathrm{O}$ measurement and urinoculture results

\begin{tabular}{|c|c|c|c|}
\hline \multirow{2}{*}{$\begin{array}{l}\text { Sample } \\
\text { number }\end{array}$} & \multirow{2}{*}{$\begin{array}{l}\mathrm{N}_{2} \mathrm{O} \text { production } \\
\text { in urine }(\mu \mathrm{g} / \mathrm{l})^{\star}\end{array}$} & \multicolumn{2}{|l|}{ Urinoculture } \\
\hline & & Micro-organism & $c f u / m l$ \\
\hline 1 & $0 \cdot 10$ & Negative & \\
\hline 2 & 415.00 & Esherichia coli & $2 \times 10^{6}$ \\
\hline 3 & 5.73 & Citobacter freundii & $1 \times 10^{6}$ \\
\hline 4 & $2 \cdot 81$ & Enterococcus faecalis & $2 \times 10^{6}$ \\
\hline 5 & 1.04 & Negative & \\
\hline 6 & 5.59 & Escherichia coli & $2 \times 10^{6}$ \\
\hline 7 & $54 \cdot 55$ & Escherichia coli & $1 \times 10^{5}$ \\
\hline 8 & $12 \cdot 56$ & Escherichia coli & $2 \times 10^{5}$ \\
\hline 9 & $11 \cdot 10$ & Proteus mirabilis & $2 \times 10^{6}$ \\
\hline 10 & 0.45 & Negative & \\
\hline 11 & 1.98 & Enterococcus faecalis & $5 \times 10^{5}$ \\
\hline 12 & 0.73 & Negative & \\
\hline 13 & $50 \cdot 00$ & Escherichia coli & $2 \times 10^{5}$ \\
\hline 14 & 1.01 & Negative & \\
\hline 15 & $13 \cdot 12$ & Escherichia coli & $2 \times 10^{6}$ \\
\hline 16 & 1.56 & Pseudomonas aeruginosa & $1 \times 10^{6}$ \\
\hline
\end{tabular}

$\star$ Production of $\mathrm{N}_{2} \mathrm{O}$ in urine as measured by headspace gas chromatography.
$\mathrm{N}_{2} \mathrm{O}, 0-5 \mathrm{mg} / \mathrm{l}$, not significantly higher than blank controls.

MONITORING OF $\mathrm{N}_{2} \mathrm{O}$ PRODUCTION DURING BACTERIAL GROWTH

Figure 2 shows the amount of $\mathrm{N}_{2} \mathrm{O}$ produced by Enterobacter aerogenes at different times.

The $\mathrm{N}_{2} \mathrm{O}$ values in fig 2 seem to be lower than those in table 1 probably because of the difference in the initial inoculum $\left(1 \times 10^{5}\right.$ and $1 \times 10^{6} \mathrm{cfu} / \mathrm{ml}$, respectively).

The production of $\mathrm{N}_{2} \mathrm{O}$ depends on incubation time: it is low during the first five hours of incubation, then increases exponentially up to 24-36 hours. Prolonged incubation does not lead to further increase of $\mathrm{N}_{2} \mathrm{O}$ production: the plateau is reached at $\mathbf{4 8}$ hours.

CORRELATION BETWEEN $\mathrm{N}_{2} \mathrm{O}$ MEASUREMENT AND RESULTS OF URINE CULTURE

Table 2 shows the $\mathrm{N}_{2} \mathrm{O}$ measurements and results of the urine culture.

We found a good correlation between the results of urine cultures and the measurement of $\mathrm{N}_{2} \mathrm{O}$ in urine. Urine samples negative for bacteria, considered as controls, were found to contain very low concentrations of $\mathrm{N}_{2} \mathrm{O}$ (samples numbers 1, 5, 10, 12, and 14). Samples positive for Enterobacteriaceae (samples numbers $2,3,6,7,8,9,13$, and 15) gave significantly higher $\mathrm{N}_{2} \mathrm{O}$ values. Samples infected with Gram positive cocci (numbers 4 and 11) had slightly higher $\mathrm{N}_{2} \mathrm{O}$ measurements than controls. Surprisingly, the sample positive for Pseudomonas (number 16) was negative for $\mathrm{N}_{2} \mathrm{O}$.

Thus, as expected, different microorganisms can produce different amounts of $\mathrm{N}_{2} \mathrm{O}$ as a consequence of their growth in urine and metabolic activities.

There is no clear relation between the bacterial count in urine and the amount of $\mathrm{N}_{2} \mathrm{O}$ measured: probably other factors-for example, the time since infection occurred, presence of bacteriostatic substances, or low $\mathrm{pH}$ - can interfere with such measurements.

\section{Discussion}

The urinary tract is the main site of excretion of anaesthetics, either in metabolised or unmodified form. The fluctuations in environmental concentrations are rapidily reflected in the urine because the concentration of anaesthetics in urine newly formed in the kidney is in equilibrium with the blood concentration. Assuming a constant production of urine over time, the concentration of anaesthetics in urine collected after the end of exposure is correlated with the weighted average value of a sample of air breathed during the exposure time. $^{2310}$ The urinary concentration of anaesthetics eliminated in the unmetabolised form is further weighted as the bladder acts as a collection and mixing vessel for the urine coming from the kidney. ${ }^{11}$ During the passage along the excretion system and, especially, during the stay in the bladder, it is possible that $\mathrm{N}_{2} \mathrm{O}$ produced by micro-organisms adds to that introduced by inhalation. Moreover, if the 
urine sample is not correctly stored (for example at room temperature or for long periods of time) further $\mathrm{N}_{2} \mathrm{O}$ production could occur due to the microbial proliferation in the vials used for analysis.

Bacteria produce $\mathrm{N}_{2} \mathrm{O}$ as a consequence of their metabolism of nitrogen. Several mechanisms are possibly involved, including the oxidation of ammonia and nitrite to nitrate (nitrification) and conversely the reduction of nitrate. If molecular nitrogen is the main product of nitrate reduction, the process is called denitrification. Denitrifier micro-organisms, which encompass species of various genera, reduce nitrate to nitrite, then to $\mathrm{N}_{2} \mathrm{O}$ and finally to nitrogen. Other bacteria-for instance mostly enterobacteria and staphylococci-reduce nitrate only to the level of nitrite and that is excreted (nitrate/nitrite respiration). Several organisms reduce nitrite further to ammonia (nitrate ammonification). Members of Enterobacteriaceae produce small amounts of $\mathrm{N}_{2} \mathrm{O}$ although they are not true denitrifiers. ${ }^{12}$

Our results showed that several microorganisms frequently responsible for urinary tract infections can actually produce $\mathrm{N}_{2} \mathrm{O}$. We noted that the amount of $\mathrm{N}_{2} \mathrm{O}$ producion varies. Generally speaking, Gram negative bacilli are high producers, whereas Gram positive cocci are not. The amount of $\mathrm{N}_{2} \mathrm{O}$ produced depends not only on the species of micro-organism but also on the initial bacterial load in the sample and on the delay between sample harvesting and $\mathrm{N}_{2} \mathrm{O}$ measurement. We noted that the steady state for the bacterial growth in urine is reached after 45-50 hours.

Normal conditions of sample storage - that is, addition of acetic acid to the urine mantained at $4^{\circ} \mathrm{C}$-do not seem to be sufficient to prevent the preanalytical error linked to the presence of bacteria during the routine monitoring of exposure to anaesthetic gas. We think that there are two probable explanations for this finding. Firstly, is that some species of bacteria are relatively acid tolerant and can survive and reproduce at a low pH. Escherichia coli, for instance, can survive at $\mathrm{pH} 4.5$. Secondly, and probably the more plausible explanation is that $\mathrm{N}_{2} \mathrm{O}$ is produced in the bladder and is already present in freshly harvested urine. To investigate this possibility we examined four patients with positive urine cultures, whose samples were collected and immediately processed and analysed for $\mathrm{N}_{2} \mathrm{O}$ content. We found $\mathrm{N}_{2} \mathrm{O}$ concentrations of 4 ,
27,91 , and $110 \mathrm{mg} / 1$ (data not reported on table 2 ). The $\mathrm{N}_{2} \mathrm{O}$ production agreed well with the result of the urine cultures and the bacterial count. Our findings suggest that the different concentrations of $\mathrm{N}_{2} \mathrm{O}$ detected could also be linked to the period of onset of the infection.

\section{Conclusion}

In conclusion, the confounding effect connected with the presence of bacteria, seems to be the difficulty in control by means of current antimicrobial strategies. Therefore, the possible outliers should be identified, mainly on the basis of the information concerning exposure $\left(\mathrm{N}_{2} \mathrm{O}\right.$ in air, urinary $\mathrm{N}_{2} \mathrm{O}$ concentration in other workers operating in the same room, etc) and verifying the clinical history of urinary tract infections. Additional validation of the bacterial source of $\mathrm{N}_{2} \mathrm{O}$ in urine may be gained by finding blood $\mathrm{N}_{2} \mathrm{O}$ concentrations which are lower than expected.

1 Sonander HG, Stenqvist O, Nilsson K. Exposure to trace amounts of nitrous oxide. Evaluation of urinary gas content monitoring in anaesthetic practice. $\mathrm{Br} \mathcal{F}$ Anaesth 1983;55:1225-92.

2 Sonander HG, Stenqvist $\mathrm{O}$, Nilsson $\mathrm{K}$. Urinary $\mathrm{N}_{2} \mathrm{O}$ as a measure of exposure to nitrous oxide anaesthetic contamination. Ann Occup Hyg 1983;27:73-9.

3 Imbriani M, Ghittori S, Pezzagno G, Capodaglio E Nitrous oxide $\left(\mathrm{N}_{2} \mathrm{O}\right)$ in urine as biological index of exposure in operating room personnel. Appl Ind Hyg 1988; 3:223-7.

4 Stevens MP, Walrand J, Buchet JP, Lauwerys $R$. Evaluation de l'exposition à l'halothane et au protoxide d'azote en salle d'operation par des mesures d'ambiance et des mesures biologiques. Cahiers de Medecine de Travaille $1987 ; 34: 1-41$.

5 Sonander HG, Stenqvist O, Nilsson K. Nitrous oxide exposure during routine anaesthetic work. Measurement of biological exposure from urine samples and technical exposure by bag sampling. Acta Anaesthesiol Scand 1985; 29:203-10

6 Brugnone F, Perbellini L, Cerpelloni M, Cecco A, Giuliani $G$. Nitrous oxide in blood and urine of operating theatre personnel and the general population. Int Arch Occup Environ Health 1995;68:22-6.

7 Pezzagno G, Imbriani M, Ghittori S. Inhalation anaesthetics. In: CEC Report. Biological indicators for assessment of human exposure to industrial chemicals. CEC Repor 1989;6:47-76.

8 Maina G, Pavan S, Cerutti S, Buglione E, Scansetti G. Possibili interferenze microbiologiche nella determinazione dei valori di protossido di azoto urinario in lavoratori esposti a gas anestetici. Atti $2^{\circ}$ Congresso Nazionale Medicina Preventiva Lavoratori della Sanità. Brescia, Gargnano: 1994;508-10.

9 Bleakley BH, Tiedje JN. Nitrous oxide production by organisms other than nitrifiers or denitrifiers. Appl organisms other than nitrifiers

10 Krapez JR, Saloojee V, Hinds CJ, Hackett GM, Cole PV Blood concentrations of nitrous oxide in theatre personnel. Br f Anaesth 1980;52:1143-8.

11 Ghittori S, Imbriani M, Pezzagno G, Capodaglio E. The urinary concentration of solvents as a biological indicator of exposure: proposal for the biological equivalent exposure limit for nine solvents. Am Ind Hyg Assoc $\mathcal{F} 1987$ 48:786-93.

12 Stewart V. Nitrate respiration in relation to facultative metabolism in enterobacteria. Microbiol Rev 1988;52: 190-232. 